\title{
Institutional caregiver experiences in child care
}

Vivências do cuidador institucional no acolhimento infantil

Vivencias del cuidador institucional en la acogida infantil

Ruth Irmgard Bärtschi Gabatz ${ }^{1}$

Eda Schwartz ${ }^{1}$

Viviane Marten Milbrath ${ }^{1}$ (i)

1. Universidade Federal de Pelotas. Pelotas,

RS, Brasil
Corresponding author:

Ruth Irmgard Bärtschi Gabatz.

E-mail: r.gabatz@yahoo.com.br.

Submitted on $06 / 28 / 2018$

Accepted on 12/27/2018.

DOI: 10.1590/2177-9465-EAN-2018-0195

\section{Abstract}

Objective: to know the experience of institutional caregivers in child care. Method: qualitative research that used the Attachment Theory and the Symbolic Interactionism. Fifteen caregivers were interviewed, in 2015, in a child care institution based in a municipality in the south of Brazil. Data were analyzed through content analysis. Results: two categories emerged from the study: Embracing the children in the institution; Helping children adapt to institutionalization. Institutionalization imposes several social ills, such as abandonment and violence. These must be faced by caregivers, generating sadness and revolt. In addition, institutionalization leaves a mark on the child's life, which belongs to no one, nor has his individuality and subjectivity preserved. Conclusion and implications for practice: it is necessary to provide caregivers psychological support and Permanent Education so that they are supported in the work, improving the conditions of care offered to the child.

Keywords: Child, Institutionalized; Caregivers; Interpersonal Relations; Qualitative Research; Nursing.

\section{Resumo}

Objetivo: conhecer a vivência do cuidador institucional no acolhimento infantil. Método: pesquisa qualitativa que utilizou a Teoria do Apego e o Interacionismo Simbólico. Entrevistaram-se 15 cuidadoras, no ano de 2015, em uma instituição de acolhimento infantil de um município do sul do Brasil. Analisaram-se os dados por meio da análise de conteúdo. Resultados: duas categorias emergiram do estudo: Acolhendo as crianças na instituição; Auxiliando as crianças na adaptação à institucionalização. A institucionalização impõe diversas mazelas sociais, como o abandono e a violência. As mesmas precisam ser enfrentadas pelas cuidadoras, gerando tristeza e revolta. Além disso, a institucionalização inflige uma marca para a vida da criança, que não pertence a ninguém, nem tem sua individualidade e subjetividade preservada. Conclusão e implicações para prática: é preciso proporcionar às cuidadoras suporte psicológico e Educação Permanente para que estejam respaldadas no trabalho, melhorando as condições do atendimento oferecido à criança.

Palavras-chave: Criança Institucionalizada; Cuidadores; Relações Interpessoais; Pesquisa Qualitativa; Enfermagem.

\section{Resumen}

Objetivo: conocer la vivencia del cuidador institucional en la acogida infantil. Método: investigación cualitativa que utilizó la Teoría del Apego y el Interaccionismo Simbólico. Se entrevistó a 15 cuidadoras, en el año de 2015, en una institución de acogida infantil de un municipio del sur de Brasil. Se analizaron los datos a través del análisis de contenido. Resultados: emergieron dos categorías del estudio: Acogiendo a los niños en la institución; Auxiliando a los niños en la adaptación a la institucionalización La institucionalización impone varios males sociales, como el abandono y la violencia, los cuales necesitan ser enfrentados por las cuidadoras, generando tristeza y revuelta. Además, la institucionalización inflige una marca para la vida del niño, que no pertenece a nadie, ni tiene su individualidad y subjetividad preservadas. Conclusión e implicaciones para la práctica: es necesario proporcionar a las cuidadoras soporte psicológico y Educación Permanente para que estén respaldadas en el trabajo, mejorando las condiciones de la atención ofrecida al niño.

Palabras clave: Niño Institucionalizado; Cuidadores; Relaciones Interpersonales; Investigación Cualitativa; Enfermería. 


\section{INTRODUCTION}

Child institutionalization is an exceptional and provisional measure used to offer children a protection place when they cannot stay with their parents. ${ }^{1}$ Abandonment, neglect, use of psychoactive substances as well as the absence or immaturity by the caregivers are among the determinants that lead to this need, ${ }^{2}$ which interferes with motherhood and parenthood. ${ }^{3}$ However, separation from family should occur only when it represents the last resort to minimize the damage to the child's development, that is, in situations of serious risk to her physical or mental integrity. ${ }^{1}$

However, although the child needs protection, the best place for their development is with the family, because the child and the adolescent have the right to be raised by this or a surrogate family, guaranteeing them family and community living. ${ }^{1}$ In this context, the family should be embraced and strengthened so that it would be able to continue with its children. This can be achieved through public policies that invest in guaranteeing the rights of children and adolescents to remain with their family ties, ${ }^{4}$ instead of welcoming them into institutions. Therefore, considering the maintenance of family and community ties as a priority for child development, it is necessary, whenever possible, to seek the reintegration of children in institutional care.

However, when institutionalization is unequivocal, it is necessary to provide an adequate environment for the embracement, with sensitive and attentive caregivers that can help with the development of stable relationships with institutionalized children. ${ }^{2}$ Thus, individualized care should be emphasized, since the tie's quality influences the emotional, cognitive and social development of children. ${ }^{5}$ Thus, considering that socialization plays a fundamental role in human development, ${ }^{6}$ the establishment of secure bonds provides more effective social interactions, being essential in the children's psychological quality of life. ${ }^{7}$

In addition to the impact of institutionalization on children, caregivers also suffer from the situation, presenting high levels of stress that affect their health and interfere in the quality of their relationship with the embraced ones. ${ }^{8}$ In view of this, it should be emphasized that it is the responsibility of the institutional caregiver to interact and provide children affection so that they can develop secure ties. ${ }^{7}$ However, the caregiver often does not feel prepared for this task, which causes her suffering and sadness. ${ }^{9}$ In this context, the ideas of Symbolic Interactionism can be inserted and linked to the process of interaction in which caregivers and children interact by acting, perceiving, interpreting and acting again. Thus, they are actors and reactors in the active process in the world, modifying their perspectives and attributing symbols and meanings to their experiences. ${ }^{6}$ Moreover, when taking into account the Attachment Theory, it is perceived that the formation of bond with the caregiver in the child institutionalization reflects the children's need of a main figure of attachment, who provides them security and protection for their physical and mental development. ${ }^{7}$

There is a gap in nursing studies regarding the evaluation of this subject, considering this the profession whose objective is the care and its action in the child care across different contexts. It is observed that it is little inserted in child care institutions. It is believed that nursing can contribute to the improvement of care provided at these institutions with the creation of strategies that facilitate formation of bonds and provide support for care, thus reducing the vulnerabilities of children and caregivers.

Faced with this problem, this study aims to know the experience of institutional caregivers in child care from the following research question: "How does the institutional caregiver live the child care?"

\section{METHOD}

This is a qualitative research that used as a theoretical framework the Attachment Theory ${ }^{7}$ ) and the Symbolic Interactionism. ${ }^{6}$ The Attachment Theory presents the importance of safe bonds formation for the healthy development of human beings. Bond and attachment behaviors are triggered by various actions by both the caregiver and the being cared for. ${ }^{7}$ Meanwhile, human beings learn about Symbolic Interactionism and begin to understand their environment through interaction with others. ${ }^{6}$ The approach of these two theories is important because, in institutionalization, the child abandons the context known by her, needing to adapt to a new reality with different routines, spaces and relations. In addition, the caregiver must help the child in this adaptation and also adapt to new ways of providing care.

The research was carried out in a child care institution, which embraces female and male children, from zero to eight years old, and is based in a municipality in southern Brazil. 15 professionals involved in direct care (feeding, bathing, changing diapers, among others) of children from zero to three years participated in the study, because this is the phase in which the bond with the main figure of care occurs and attachment is developed. ${ }^{7}$ The inclusion criteria for caregivers were: to work in the institution for at least three months and provide direct care for the children of the age group established for the research. The technical staff was excluded because they did not provide continuous direct care for the children. A caregiver who had been in the institution for less than a month was excluded as well.

The data were collected between April and August 2015, in the three shifts (morning, afternoon and night), scheduling the meetings previously, according to the availability of participants. The intensive interview with the caregivers was used for the collection, with broad and open-ended guiding questions. This type of interview allows for a detailed analysis of a given topic, providing an explanation of each participant's interpretation of their experience. ${ }^{10}$ All participants signed the Free and Informed Consent Form, agreeing to their voluntary participation in the study.

The interviews lasted about 30 minutes and were recorded on a MP3 player in a private room inside the child care institution, being transcribed manually in full. The data were analyzed through conventional content analysis, where the coding categories are directly derived from the textual data. ${ }^{11}$ In this type of analysis, data are first read word by word in order to identify codes, cap- 
turing thoughts or concepts. In a second step, the codes are labeled, which results in an initial coding. Subsequently, categories and subcategories will emerge. ${ }^{11}$ Data were analyzed manually through inductive analysis, as exemplified in the following Table:

Table 1. Organization of data analysis, Pelotas, RS, Brazil, 2015

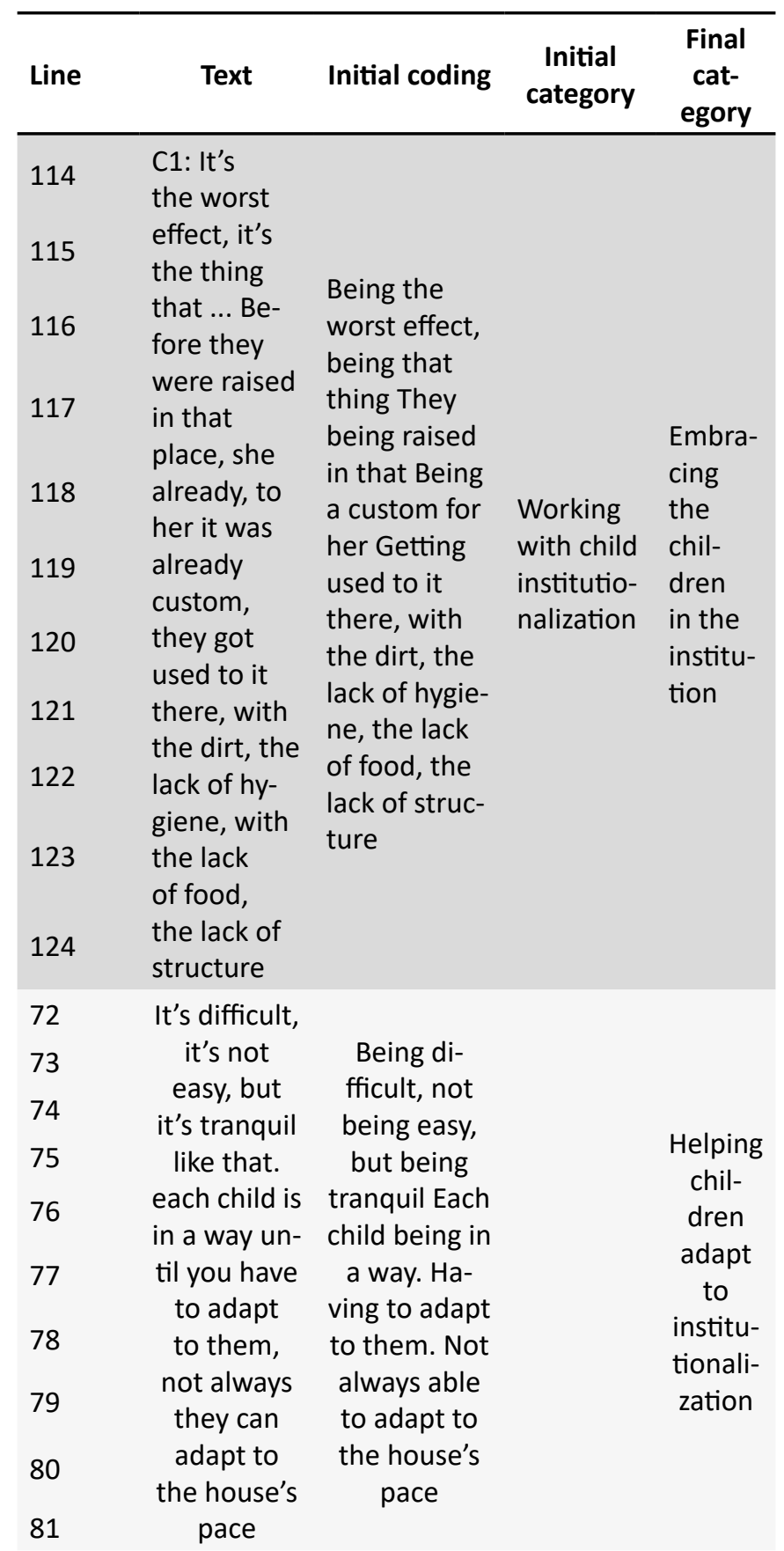

Thus, from the initial category, Working with child institutionalization, two final categories were elaborated: Embracing the children in the institution; Helping children adapt to institutionalization. All ethical precepts for human research were observed as provided in Resolution 466/12. ${ }^{12}$ Thus, caregivers not only agreed to participate in the study, but also had their anonymity maintained. All participants were named with the letter $\mathrm{C}$, followed by a sequential numeral $(\mathrm{C} 1, \mathrm{C} 2, \ldots)$. The proposal of this study was submitted to the Research Ethics Committee under Opinion 1,035,995 and CAAE (Certificado de Apresentação para Apreciação Ética - Certificate of Presentation for Ethical Consideration) 42696915.9.0000.5316, being approved on 04/26/2015.

\section{RESULTS}

Twenty-five female caregivers, aged 22 to 58 years, with education background from complete primary education to full tertiary education, and with a period of time in the institution from eight months to 12 years participated in the study. Nine were single, four married, one was divorced and one lived in concubinage. In addition, nine had children whose ages ranged from eight months to 31 years.

The work of caregivers goes through several stages during the institutionalization of children, in this process they stand out: embracement, adaptation of the child and preparation for leaving the institution. Two categories were listed to present the results: Embracing the children in the institution; Helping children adapt to institutionalization.

\section{Embracing the children in the institution}

At embracement, participants highlight the difficulty of working with children who come from realities in which they suffered violence and neglect. This reality includes the lack of essential conditions related to hygiene, food and material structure, which imposes restrictions on children and, at the same time, makes them get used to this context.

It's the worst effect [...] they were raised there, [...] they got used to that, with the dirt, the lack of hygiene, the lack of food, the lack of structure

\section{$[\ldots]$ of the house (C1).}

[...] some already arrive with two, three years old [...].So they already come from a very different reality (C2).

Family's withdrawal and institutionalization impose on the child the need to adapt to another reality, different from what she 
got used to. Caregivers need to help the child to enter into this new reality, looking for ways to make the care more similar to what she was accustomed to:

[...] there were kids who did not bath. [...] the child tried to take a shower, shower did not work, we tried in the bathtub and nothing worked (C1).

[...] he does not eat, he only drank milk when he was with his mother and there were nights he does not eat. He has lunch a little [...] we try to make him understand [...] (C5).

Institutionalization also imposes on the child a break in the relationship with her family and her daily life, causing difficult situations for the caregivers.

[...] when a young child arrives like this is bad, because often the child comes from home. Often the child is taken from the mother, and there until you deal with the child, [...] it's hard (C8).

Oh, it's harsh, [...] even more when it's a little baby, they suckled and spent the night crying because of the breast, because of the mother, it's complicated, it's difficult, you have to handle it $[\ldots](\mathrm{C} 13)$.

In this context, the child insertion in the institution affects the children and caregiver emotional state. Caregivers need to manage the child insertion into the institution and their own feelings before the reality lived. Complementarily, the change of context and remoteness of the family also causes suffering, because the child does not recognize her new reality.

We should treat their mind I think. [...], because they already come with that feeling of rejection, of abandonment, of suffering. You see a girl, a child of two, three years, she understands that she is no longer in her house, in her room, that she is no longer with those people that she had bond. There she comes in is a shock, "I'm not in my bed anymore, where is my mother?" (C10).

On the other hand, as reported below, the situations that led the child to be institutionalized, such as maltreatment, abuse, history of drug use by the parents, lack of food and toys, also caused suffering. Caregivers perceive that the family, instead of being a source of protection, is a source of aggression and neglect.

[...] arrives an abused and mistreated child it is a difficult situation for us, because she is injured, [...].So it's kind of a shock, but you have to be prepared for that, because if not, in the end, you did nothing [...] (C3).
[...] at first it was very difficult for me [...] to see the scene of some children who have already been abused, who have been mistreated, who lived in terrible conditions, who did not have a toy, food. [...] it touches us (C9).

Although children are victims of neglect and violence, the family is a reference for them and they miss it. C5 points out that although the mother poses a risk to the child's physical integrity, she wants to stay with her mother, who represents her main attachment figure.

$[\ldots]$ they are so small for such great suffering [...]. Now we have the case [...] that the mother hurt, [...] poor thing, is crazy about that mother, even calls her to come here at night (C5).

Some caregivers understand that the lack of family members who offer support and support to mothers can lead to neglect and abandonment.

[...] / understand those mothers and why those children are here. Did they have parents together? Did you have a family to help? No, understood, then I understand if I suddenly had a father, had a mother. [...] a family support, it would be different (C1).

In addition, sometimes, caregivers' understanding regarding children in the child care institution is related to transcendence, the relationship established with themselves, with the other and with the world that surrounds them.

[...] it is an experience that they had to go through with us [...]. Just as we are included in this context [...] (C6).

\section{Helping children adapt to institutionalization}

Institutionalization, during adaptation, imposes on the child the need to adapt to the new reality. This process occurs quickly for some children, although others need a long time for this, requesting more patience from caregivers.

It's difficult, it's not easy, [...] every child is in a way, until you have to adapt to them, not always they can adapt to the house's pace. [...] they have children who do not make noise, they just arrive [...]. Others come and go on duty, [...] you have to be patient, you have to donate yourself more specifically to that child (C15).

Difficulties faced in caring for the child, such as dealing with emotions and using an appropriate approach, are sometimes related to situations experienced by children in their families, such as maltreatment and isolation. Thus, in institutionalization, 
caregivers must deal with the behavior of children who are "harder and more revolted', and seek to understand the best way to care for each one.

[...] by the situation they lived, they get harder, more rebellious, more rebellious [...] it's very difficult, it's complicated, you have to have a lot of patience, you have to know how to reach each one with a way (C5).

Participants report that some children, although they miss their family, they end up adapting to the institution because they interact with other children and have a protection place where they can demonstrate their capacity to adapt to the new context. This adaptation process begins with the child's arrival, when she comes to live and interact with caregivers and with children who are already living in the institution. In the beginning, the child calls for her mother and/or father, however, over time, she abdicates from this attitude by playing and interacting with caregivers and with other children.

[...] when she enters she says, "Oh, I want my mother" [...], she screams the first day "Mom, Mom, or Dad, Dad", I don't know. In the second, she wants to play, she wants to watch a television, she wants to interact, she is already calling you auntie [...], she asks very rarely (C4)

On the other hand, institutionalization leaves marks related to abandonment, breaking of bond with the family and status of institutionalized child, generating a burden for the rest of life.

[...] after you've gone to an institution, it's a mark that's forever. [...] you went to a shelter, you are a child of an institution and you are no one, there is no one expecting anything from you, you have been abandoned (C14).

Caregivers realize that they must meet the child's needs denied by their family, such as physical and emotional development, food, smile and affection, in order to grow properly.

[...] todevelop the emotional side of them, which already comes with a big thump. Motor coordination, everything that I can do as a stimulus, learn to caress, that neither they come here biting and very aggressive and everything else, because they do not know affection, understand? They do not know how to smile, they do not have the sparkle in their eyes, to bring it back, because in those early years we know how important this is, [...] and then many arrive here without it, it had been stolen, it's hard. (C14).

In this context, it is necessary to prepare the child so that she can rejoin her family or a surrogate family when she leaves the institution. $\mathrm{C} 14$ sees the institution as the place where children have an opportunity to create new bonds.

To prepare her to leave here, to have another chance out there, or the family that will be rearranged to get her back, or family to receive her in an adoption. She has to interact well, she has to be prepared for it [...] (C14).

Thus, considering the institutionalization process and its stages, caregivers need to help children to overcome situations, teaching them to have limits, as explained in the following report, and thinking about their development for the future.

[...] there are certain situations that we cannot let the emotion speaks louder, [...] he has to learn to overcome it there, if you start to hand over, let the things done wrong, because there are some that are raised in the shelter, what will happen the future? (C5).

Children, during institutionalization, receive care and education from participants. However, according to $\mathrm{C} 14$, it is necessary to adopt a different conduct with children. Often, in relation to donations, where clothes and toys are always being replaced, ends up giving the children the idea that it is not necessary to take care of objects, therefore many were spoiled. Care, as an action to receive from others what it needs, also has a negative bias for children development to always wait for someone who offers what is lacking, being able to limit it in the search for her ideals.

[...] here we have the donations issue, [...] every time something is damaged, because it is nobody's and the child is in it, is accustomed that soon someone will give [...] it had to be different [...] the assistance thing. [...] since little ones they are accustomed to someone offering something, as if life were this way, but it is not (C14).

In addition, institutionalization imposes on the child a series of restrictions, such as staying in an enclosed space with few opportunities to go out to meet other places, and there are sporadically brief exits.

[...] they are very restricted here, they do not have contact with the street to see different things. [...] they are locked in an environment, think of you living 24 hours a day in a house, in a place where only people who come to take care of you (C7).

[...] there's not much to do with shelter kids, they spend pretty much all day here in the shelter. There, sometimes, is a ride or another [...] (C13).

Caregivers understand that the institution is not a suitable place for the child's development, and that this should occur with 
a family. Therefore, they hope that children will be adopted, and the institution is only a temporary experience.

[...] I hope he's gone, because it's better to go to a home than to be here., [...] they need to have an attention of father and mother that they do not have here [...] (C7).

\section{$[\ldots]$ this is not life, [...] it has to be something temporary (C11).}

Institutionalization should be a temporary condition, as recommended by the Statute of the Child and Adolescent (Estatuto da Criança e do Adolescente). ${ }^{1}$ However, caregivers report that this does not always occur, since some children are accepted until they are of age, which shows a gap in the system.

[...] here is not home, and we know they're going to be here until six, seven years old, and then they will go to another shelter. Then the adoption is even more difficult, and the likelihood of them going to the street when they are eighteen is even greater ( $\mathrm{C} 12)$.

\section{DISCUSSION}

The need for adjustment to life in the institution and the way that care is provided there can change the child's development, generating negative impacts on the acquirement of social, cognitive and affective skills. Therefore, it is important to know all socioeconomic, emotional and structural conditions experienced by the child before embracement, so that it is possible to adjust the care offered. However, the absence of consistent practices for documentation and monitoring of institutionalized children still constitutes one of the main barriers to knowledge of reality and deinstitutionalization. ${ }^{13}$

Many children initially do not accept the care and feeding offered by caregivers because they do not know them and have no ties with them. Mother-child separation causes affliction, which is intensified when insertion takes place in a strange environment, under the care of unknown persons. ${ }^{7}$ Therefore, there is intense emotional exhaustion of institutionalized children, especially at the time of adaptation to the institution, since it requires the immediate acceptance of habits, schedules and rules that may be very different from those experienced by the child in living with her family. ${ }^{14}$

In the process of adapting the child to the institution, the caregiver needs to develop patience, which requires greater donation for some cases, while in others this occurs more easily. When the child is separated from her main attachment figure, she tends to protest initially, and then goes through apathy and withdrawal, where she seeks new relationships. If there is a person who can play the maternal role, in time, the child will accept it and treat it in a similar way to her own mother. ${ }^{7}$

Through reports of caregivers, it is observed that children have different reactions to institutionalization, such as apathy and withdrawal. In all situations, the caregiver plays a fundamental role and can, through affective bond, promote mechanisms of protection for the mental and emotional health of these children. ${ }^{15}$ Therefore, it is essential to promote the improvement of caregivers based on their valorization and re-meaning of their role with children. They need to be prepared to assist the child in adapting to the institution, as well as to reinserting her into the family of origin or into surrogate families, where appropriate. ${ }^{16}$

During the child's adaptation to the institution, she and the caregiver develop an interaction in which both learn with each other. ${ }^{6}$ In this context, both children and caregivers begin to adopt new ways of being and acting and adapting to circumstances.

Care has a vital social value, because when it meets needs, it is the main factor promoting the cognitive, emotional and psychosocial development of children. ${ }^{17}$ Therefore, it is necessary to have greater constancy in the care of institutionalized children, with individualized attention and receptive and stable contact, since, in the presence of these, the risk of the development of inhibited attachment and disorganized behavior in children is reduced. ${ }^{18}$ Thus, the guarantee of a care that considers the individuality and subjectivity of the child enables a better quality. ${ }^{19}$

Neglect of care of food, hygiene, caring and physical and emotional violence suffered by children in their families brings suffering to caregivers, making work performance difficult, especially in the first experiences and in those in which signs of maltreatment are more evident. These situations 'touches us' and can be 'shocking'. Caregivers stress that it is necessary to "be prepared" for this, otherwise they cannot do anything to face the situation. Caregiver's stress can be reduced through Lifelong Learning and support services, allowing it to continue with its role without compromising quality of life, nor the care offered..$^{20}$

Socially, child institutionalization is still linked to the socioeconomic fragility of families. ${ }^{21}$ In this perspective, it would be necessary to work on the reconstruction of family ties, with a view to providing support for families to reorganize themselves, reviewing their invisibility in the child care institutions and favoring the maintenance of family ties. ${ }^{22}$

In addition, it is important to look at how the child's family is signified by the professionals who provide care in embracement services. Negative conceptions about the family make the children feel even more stigmatized and distant from their original environment, fearing to resume their family ties. If the family is disqualified to provide care, it will not have room within the institutions to reconnect with their children. ${ }^{23}$

However, it is hard for caregivers to cope with such situations. Although they recognize the need not to stigmatize the children families who are living in generational cycles of violence, they are indignant at the condition presented by some children, expressing their feelings of sadness and revolt. In this context, the lack of family support is understood as generating institutionalization of children. For caregivers, if institutionalized child parents had a support network that would help minimize their vulnerability, they could adequately care for their children. 
Still, for some caregivers, the issue of child care is understood as something predetermined, an experience through which they had to go, helping in the confrontation and acceptance of daily life. Thus, caregivers begin to re-mean their way of perceiving themselves in the world from experiences they share with institutionalized children, which makes them adopt new symbols and meanings for their existence and for their work. ${ }^{6}$

Participants perceive the importance of offering a receptive, patient, and friendly response, identifying the best way to deal with each child, so that an approach is possible. However, this is a complicated process where caregivers lack in preparation for how to 'reach each one'. Caregivers need to provide emotional support to institutionalized children, but they may not be able to do so because they are not. Therefore, it is essential that they have ongoing psychological support and updating so that they can elaborate new ways of acting, based on professional experiences. ${ }^{24}$

Caregivers understand embracement as a stigmatizing situation, which leaves a mark on the children, related to abandonment. This is because the child comes to be seen as someone who belongs to an institution and not linked to a family. Thus, in child institutionalization, it is essential to have a caregiver capable of listening, making investments that go beyond functionalist interests and provide the possibility of re-meaning experiences, avoiding focusing only on erasing negative experiences. ${ }^{25}$

Caregivers are worried about supplying what the children did not have in their families, which represents the interest in taking care of the other. However, they understand the need to educate children, imposing limits on them within the institution. These limits are passed on by the caregivers so that the children can understand that all must respect the norms, becoming aware of their importance in life in community.

On the other hand, caregivers understand that it is necessary to review the donations issue, in which the constant substitution of objects leads to high discard. The child, as an individual inserted in this collective context, does not perceive herself responsible for objects, nor understands them as hers, spoiling and discarding many things, which can be interpreted as lack of valorization. ${ }^{26}$ However, because they are from an institution, it is considered necessary to teach them that they should accept and thank for everything, even if it does not serve them. Considering current symbols and meanings in society, ${ }^{6}$ this perception of caregivers reflects their perspectives, which are child care institutions as places of care and support in which children need to have their physical, emotional, and material needs met. So when children spoil and discard what they receive, they break with the expected order of acceptance and check the actual need for donations. ${ }^{26}$

Caregivers are also concerned about the constraints caused by the confinement of institutionalized children, understanding that it would require a greater interaction of these children with the external world. However, most of the time, they have no way to provide this, due to the lack of professionals to accompany children on rides. In this context, it is worth remembering that participation in the community's daily life, with access to cultural, sports and leisure activities, is indispensable for the development of children's autonomy and for their socialization. ${ }^{27}$ One of the ways to alleviate the problem could be affective patronage, seeking to ensure family and community coexistence with institutionalized children, expanding their networks of relationships and favoring the establishment of new bonds of affection. ${ }^{28}$

Caregivers emphasize the need for family living for institutionalized children, so that they can develop a bond that is the basis for their life. Family and community contact could be preserved through visits from family members and persons representing the child's community of origin. ${ }^{27}$ In addition, it is necessary to encourage community participation in embracement services and to strengthen the relationship between the embraced ones and the community so that children can participate and transform their social environment. ${ }^{24}$

\section{CONCLUSIONS AND IMPLICATIONS FOR THE PRACTICE}

Child institutionalization exposes various social ills, including abandonment and physical and emotional violence. Caregivers need to deal with those issues that afflict their emotional and require preparation. This training can be offered through Permanent Education and psychological support.

In their daily lives, caregivers seek to offer institutionalized children care and support, as well as supply their food, hygiene and clothing needs. In this context, it is also important to impose limits, and it is imperative that children learn to live together within the institution.

Institutionalization is also perceived as an opportunity for the child to interact with different people, developing herself physically, emotionally and psychologically. However, despite caregivers' efforts to provide children everything they lacked in her family of origin, they understand that the institution is far from home, and the family environment is the best place for these children. Separating family from the child must be carefully analyzed, since family life is the best option for her, since family is their context, their culture, their individuality and their identity.

The study limits are related to an intentional sample of caregivers of children from zero to three years. It is believed that the inclusion of caregivers of children over three years could bring different perspectives, considering that these children have other needs. Thus, the nurse insertion is very important, considering that it could provide support for care and foster the bond development between caregivers and children and help to reduce vulnerabilities inserted in the institutionalization context.

\section{REFERENCES}

1. Presidência da República (BR). Lei № 8.069 de 13 de Julho de 1990. Dispõe sobre o Estatuto da Criança e do Adolescente e dá outras providências. Brasília (DF): Diário Oficial da União; 1999 [Internet]. [cited 2016 Nov. 10]. Available from: http://www.planalto.gov.br/ccivil_03/LEIS/ L8069.htm 
2. Dias GB, Pedroso JS, Santos ACSL. Avaliação de desenvolvimento de bebês em acolhimento institucional com "Ages and Stages Questionnaries". Mudanças Psicol Saúde [Internet]. 2015;23(2):1-7. Available from: https://www.metodista.br/revistas/revistas-ims/index. php/MUD/issue/view/384

3. Valentim NS, Yamamoto K. Estudo de aspectos adaptativos e psicológicos de mães de crianças acolhidas em abrigos. Psicol Argum [Internet]. 2014;32(77):53-62. Available from: https://periodicos.pucpr. br/index.php/psicologiaargumento/article/view/19781

4. Furlan V, Sousa TRP. Família, acolhimento institucional e políticas públicas: um estudo de caso. Rev Psicol Polit [Internet].2014;14(31):499516. Available from: http://pepsic.bvsalud.org/scielo.php?script=sci_ arttext\&pid=S1519-549X2014000300006

5. Salinas-Quiroz F, Posada G. MBQS: método de evaluación para intervenciones em apego dirigidas a primera infancia. Rev Latinoam Cienc Soc Niñez Juv [Internet]. 2015; [cited 2016 Nov 10]; 13(2):105163. Available from: http://www.scielo.org.co/scielo.php?pid=S1692715X2015000200036\&script=sci_abstract\&tIng=es

6. Charon JM. Symbolic Interactionism: an introduction, an interpretation, an integration. 10th ed. Boston: Pearson Prentice Hall; 2010.

7. Bowlby J. Apego: a natureza do vínculo. $3^{\underline{a}}$ ed. São Paulo: Martins Fontes; 2009.

8. Çatay Z, Kologlugil D. Impact of a support group for the caregivers at an orphanage in Turkey. Infant Ment Health J [Internet]. 2017 Mar; [cited 2017 Jan 5]; 38(2):289-305. Available from: https://www.ncbi.nlm.nih. gov/pubmed/28236315

9. Lima SCC. O Trabalho do Cuidado: Uma Análise Psicodinâmica. Rev Psicol Organ Trab. [Internet]. 2012 May/Aug; [cited 2016 Jan 10]; 12(2):203-16. Available from: http://pepsic.bvsalud.org/pdf/rpot/v12n2/ v12n2a06.pdf

10. Charmaz K. A construção da teoria fundamentada: guia prático para análise qualitativa. Porto Alegre: Artmed; 2009.

11. Hsieh HF, Shannon SE. Three Approaches to Qualitative Content Analisys. Qual Health Res [Internet]. 2005 Nov; [cited 2018 Jun 22]; 15(9):1277-88. Available from: http://journals.sagepub.com/doi/ abs/10.1177/1049732305276687

12. Brasil. Conselho Nacional de Saúde. Resolução № 466, de 12 de dezembro de 2012. Diretrizes e Normas regulamentadoras de pesquisa envolvendo seres humanos [Internet]. Brasília (DF): Conselho Nacional de Saúde; 2012 [cited 2017 Oct 19]. Available from: http://www. conselho.saude.gov.br/resolucoes/2012/Reso466.pdf

13. Berens $A E$, Nelson $C A$. The science of early adversity: is there a role for large institutions in the care of vulnerable children? Lancet [Internet]. 2015 Jul; [cited 2018 Jan 5]; 386(9991):388-98. Available from: http:// www.thelancet.com/pdfs/journals/lancet/PIIS0140-6736(14)61131-4. pdf

14. Cavalcante LI, Corrêa LS. Perfil e trajetória de educadores em instituições de acolhimento infantil. Cad Pesqui [Internet]. 2012;42(146):494-517. Available from: http://www.scielo.br/scielo. php?pid=S0100-15742012000200010\&script=sci_abstract\&tlng=pt

15. Conzatti R, Mosmann C. Resiliência em crianças acolhidas: suas percepções sobre as adversidades. Psicol Rev (Belo Horizonte) [Internet]. 2015;21(2):352-78. Available from: http://pepsic.bvsalud. org/scielo.php?script=sci_arttext\&pid=S1677-11682015000200009

16. Hueb MFD. Acolhimento institucional e adoção: uma interlocução necessária. Rev SPAGESP [Internet]. 2016;17(1):28-38. Available from: http://pepsic.bvsalud.org/scielo.php?script=sci_arttext\&pid $=$ S1677-29702016000100004
17. Tryphonopoulos PD, Letourneau N, Ditommaso E. Attachment and caregiver-infant interaction: a review of observational-assessment tools. Infant Mental Health J [Internet]. 2014 Nov/Dec; [cited 2018 Jan 5]; 35(6):642-56. Available from: http://onlinelibrary.wiley.com/doi/10.1002/ imhj.21461/pdf

18. Corval R, Belsky J, Baptista J, Oliveira P, Mesquita A, Soares I. Inhibited attachment disordered behavior in institutionalized preschool children: links with early and current relational experiences. Attach Hum Dev [Internet]. 2017 Dec; [cited 2018 Jan 5]; 19(6):598-612. Available from: https://escholarship.org/uc/item/0cw5x298

19. Trivellato AJ, Carvalho $C$, Vectore $C$. Escuta afetiva: possibilidades de uso em contextos de acolhimento infantil. Psicol Esc Educ [Internet] 2013 Jun/Dec;17(2):299-307. Available from: http://www.scielo.br/pdf/ pee/v17n2/v17n2a12.pdf

20. Betini RSD, Hirdes JP, Lero DS, Cadell S, Poss J, Heckman G. A longitudinal study looking at and beyond care recipient health as a predictor of long term care home admission. BMC Health Serv Res [Internet]. 2017 Nov; [cited 2018 Jan 5]; 17(1):709. Available from: https://www.ncbi.nlm.nih.gov/pmc/articles/PMC5680746/ pdf/12913_2017_Article_2671.pdf

21. Zappe JG, Yunes MAM, Dell'Aglio DD. Imagens de famílias com crianças e adolescentes: impacto do status socioeconômico e da institucionalização. Pensando Fam [Internet]. 2016 Jul; [cited 2018 Jan 5]; 20(1):83-98. Available from: http://pepsic.bvsalud.org/pdf/penf/ v20n1/v20n1a07.pdf

22. Costa ACR, Cavalcante LIC, Pontes FAR. Metas e estratégias de socialização de pais e avós de crianças em acolhimento institucional. Gerais Rev Interinst Psicol [Internet]. 2015 Jan/Jun; [cited 2018 Jan 5]; 8(1):94-110. Available from: http://pepsic.bvsalud.org/pdf/gerais/v8n1/ v8n1a08.pdf

23. Silva ML, Arpini DM. Nova Lei Nacional de Adoção: revisitando as relações entre família e instituição. Aletheia [Internet]. 2013;40:43-57. Available from: http://pepsic.bvsalud.org/scielo.php?script=sci_arttex t\&pid=S1413-03942013000100005

24. Silva CDL, Denardi RC, Becker APS, Delvan JS. A psicologia nos serviços de acolhimento institucional e o fortalecimento de vínculos familiares e comunitários. Pesqui Prát Psicos [Internet]. 2015 Jan/Jul [cited 2016 Oct 31]; 10(1):55-65. Available from: http://pepsic.bvsalud. org/pdf/ppp/v10n1/05.pdf

25. Cintra AL, Souza M. Institucionalização de crianças: leituras sobre a produção da exclusão infantil, da instituição de acolhimento e da prática de atendimento. Rev Mal-Estar Subj (Fortaleza) [Internet]. 2010 Sep [cited 2016 Oct 31]; 10(3):809-33. Available from: http://pepsic.bvsalud. org/pdf/malestar/v10n3/06.pdf

26. Guedes CF, Scarcelli IR. Acolhimento institucional na assistência à infância: o cotidiano em questão. Psicol Soc [Internet]. 2014; [cited 2016 Oct 31]; 26(n.spe):58-67. Available from: http://www.scielo.br/ $\mathrm{pdf} / \mathrm{psoc} / \mathrm{v} 26 \mathrm{nspe} / 07 . \mathrm{pdf}$

27. Conselho Nacional dos Direitos da Criança e do adolescente (BR) . Conselho Nacional de Assistência Social - CNSS. Orientações Técnicas: serviços de acolhimento para crianças e adolescentes [Internet]. Brasília (DF): Conselho Nacional dos Direitos da Criança e do adolescente; 2009 [cited 2016 Jan 10]. Available from: http://www. mds.gov.br/cnas/noticias/orientacoes_tecnicas_final_pdf

28. Goulart JS, Paludo SS. Apadrinhamento Afetivo: Construindo Laços de Afeto e Proteção. Psico (Porto Alegre). 2014 Jan/Mar;45(1):3544. Available from: http://revistaseletronicas.pucrs.br/ojs/index.php/ revistapsico/article/view/12439 